\title{
Is flow velocity a significant parameter in flood damage modelling?
}

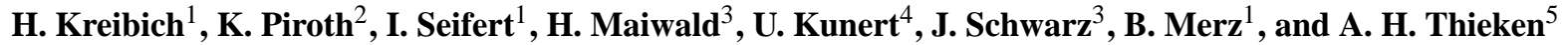 \\ ${ }^{1}$ Helmholtz Centre Potsdam German Research Centre for Geosciences (GFZ), Hydrology Section, Potsdam, Germany \\ ${ }^{2}$ ARCADIS Consult GmbH, Karlsruhe, Germany \\ ${ }^{3}$ Earthquake Damage Analysis Center (EDAC), Institute of Structural Engineering, Bauhaus-University Weimar, \\ Weimar, Germany \\ ${ }^{4}$ Deutsches Institut für Wirtschaftsforschung (DIW Berlin), Berlin, Germany \\ 5 alpS - Centre for Natural Hazard and Risk Management GmbH and Leopold-Franzens-University Innsbruck, \\ Innsbruck, Austria
}

Received: 28 February 2009 - Revised: 7 September 2009 - Accepted: 10 September 2009 - Published: 14 October 2009

\begin{abstract}
Flow velocity is generally presumed to influence flood damage. However, this influence is hardly quantified and virtually no damage models take it into account. Therefore, the influences of flow velocity, water depth and combinations of these two impact parameters on various types of flood damage were investigated in five communities affected by the Elbe catchment flood in Germany in 2002. 2-D hydraulic models with high to medium spatial resolutions were used to calculate the impact parameters at the sites in which damage occurred. A significant influence of flow velocity on structural damage, particularly on roads, could be shown in contrast to a minor influence on monetary losses and business interruption. Forecasts of structural damage to road infrastructure should be based on flow velocity alone. The energy head is suggested as a suitable flood impact parameter for reliable forecasting of structural damage to residential buildings above a critical impact level of $2 \mathrm{~m}$ of energy head or water depth. However, general consideration of flow velocity in flood damage modelling, particularly for estimating monetary loss, cannot be recommended.
\end{abstract}

\section{Introduction}

The concept of traditional flood protection is increasingly being replaced by comprehensive risk management, which includes structural and non-structural measures (Sayers et al., 2002; Hooijer et al., 2004). Hazard and risk maps are of particular importance for planning purposes, risk awareness campaigns and the encouragement of private preventive measures. "Directive 2007/60/EC of the Eu-

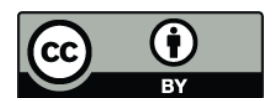

Correspondence to: $\mathrm{H}$. Kreibich (kreib@gfz-potsdam.de) ropean Parliament and of the Council on the assessment and management of flood risks" effective from 23 October 2007 (http://europa.eu/scadplus/leg/en/lvb/128174.htm) requires EU member states to develop maps identifying all areas exposed to a risk of flooding and indicating the probability of flooding for each of these areas and the potential damage for local populations, to structures and buildings and the environment. Further, decisions about (structural) flood mitigation measures are to be taken on the basis of risk analyses, since they allow us to evaluate their cost-effectiveness (e.g. Sayers et al., 2002; Ganoulis, 2003; Dawson and Hall, 2004; Merz and Thieken, 2004; Rose et al., 2007).

In these contexts, flood risk encompasses two aspects; on the one hand the flood hazard characterised by its impact parameters such as water depth and its associated probability and on the other hand vulnerability, often due to exposure and susceptibility of affected elements (Mileti, 1999; van der Veen and Logtmeijer, 2005). Thus, besides meteorological, hydrological and hydraulic investigations, such analyses require estimation of the consequences of flooding, which is normally restricted to detrimental effects, i.e. flood damage.

Probably the most comprehensive approach to flood damage models has been the "Multi-Coloured Manual" and its precursors that contain stage-damage curves for the UK (Penning-Rowsell and Chatterton, 1977; Penning-Rowsell et al., 2006). New damage models for various economic sectors in Germany were published by Thieken et al. (2008).

A central idea in flood damage estimation is the concept of damage functions or stage-damage curves, which are internationally accepted as the standard approach to assess urban flood losses (Smith, 1994). These damage models have in common that direct monetary damage is mainly related to the type or use of the building and the inundation depth (Smith, 1994; Green, 2003; Merz and Thieken, 2004). The

Published by Copernicus Publications on behalf of the European Geosciences Union. 
strong focus on inundation depth as the main determinant for flood damage might be due to limited information about other parameters characterising the flood, e.g. flow velocity. However, it implies that slowly rising riverine floods are taken as the prototype for flooding (Kelman and Spence, 2004), despite the fact that torrential rain, flash floods and groundwater flooding also cause significant damage (e.g. Kreibich and Thieken, 2008). However, these flood types and differences in damaging processes have rarely been analysed. Exceptions are investigations into damage to the building structure, caused by physical pressure on the building due to high flow velocities in steep terrain or following dam or dyke breaches (Kelman and Spence, 2003; Schwarz et al., 2005). A systematic overview of different flood impacts on buildings is given by Kelman and Spence (2004), who differentiate between the following damage mechanisms: (a) hydrostatic actions, i.e. lateral pressure and capillary rise, (b) hydrodynamic actions related to waves and velocity including turbulence, (c) erosion action by scouring away soil, (d) buoyancy action, (e) debris action including static, dynamic and erosion mechanisms, (f) non-physical actions, i.e. chemical, nuclear or biological contamination.

It is generally accepted that the higher the flow velocity of the floodwater, the greater the probability (and extent) of structural damage (Soetanto and Proverbs, 2004). USACE (1996) states that velocity is a major factor in aggravating structure and content damage. High velocities limit the time available for emergency measures (e.g. flood proofing by way of mobile protection elements) and evacuation. The additional force of high velocities creates greater danger of foundation collapse and forceful destruction of contents (USACE, 1996). For instance, McBean et al. (1988) state that a velocity of $3 \mathrm{~m} / \mathrm{s}$ acting over a $1 \mathrm{~m}$ depth will produce a force sufficient to exceed the design capacity of a typical residential wall. For these cases, an adjustment factor of $286 \%$ was suggested to allow for total building damage due to inundation alone (McBean et al., 1988). Smith (1994) shows some more critical combinations of water depth and flow velocities for building failure for three different residential building types as reported by Black (1975). For instance, these range from above $0.5 \mathrm{~m}$ water depth and $4 \mathrm{~m} / \mathrm{s}$ flow velocities to above $3 \mathrm{~m}$ water depth with no flow velocity for single storey weatherboard buildings (Smith, 1994). More failure curves for different residential buildings in the UK are presented by Kelman and Spence (2003).

The objective of this study is to analyse the importance of flow velocity for the extent of different flood damage types, i.e. structural and financial damage to residential buildings, roads and companies. Besides

- flow velocity and

- water depth, the following combinations of both were also investigated:
- total energy (energy head) according to the Bernoulli equation,

- indicator for flow force as the product of the water depth and the squared flow velocity, and

- intensity as the product of the water depth and the flow velocity.

This paper first investigates the influence of these flood impact parameters on the structural damage of buildings (Sect. 3.2.1) and road infrastructure (Sect. 3.2.2). Secondly, the influence of these parameters on monetary flood loss, primarily of residential buildings, is analysed (Sect. 3.3). Finally, correlations between these impact parameters and the business interruption/disruption duration of companies are shown (Sect. 3.4). Conclusions are drawn for flood damage modelling.

\section{Study areas, data and methods}

\subsection{Study areas}

Five municipalities in the federal state of Saxony, located in the South-East of Germany, were selected for this investigation: Dresden, Döbeln, Eilenburg, Flöha and Grimma. These municipalities were affected by a severe flood in $\mathrm{Au}-$ gust 2002 (e.g. Engel, 2004; Petrow et al., 2006), which caused more than 11 billion $€$ worth of damage in Germany. Hydraulic modelling results as well as damage records were available in these municipalities. As illustrated in Fig. 1, the communities studied are located in different hydrological settings within the catchment of the River Elbe.

Dresden is located directly on the River Elbe. However, the flood situation in Dresden in August 2002 consisted of several flood processes (see Kreibich et al., 2005a): (a) due to torrential rain, brooks caused inundation of small parts of the city on 12 August 2002. (b) on 13 August 2002, the Weißeritz and Lockwitzbach tributaries, which discharge into the River Elbe within the urban area of Dresden, brought flash floods from the Erzgebirge (Ore Mountains), which resulted in widespread inundation and caused a huge amount of damage. For example, Dresden's Central Station was flooded by the Weißeritz. (c) on 17 August 2002, the River Elbe rose to a level of $9.40 \mathrm{~m}$ at the Dresden gauge and flooded more than $9.3 \mathrm{~km}^{2}$ of the city. (d) finally, the groundwater in some parts of the city surged by $3 \mathrm{~m}$ within a few days and stayed at high levels for several months. Some of the inundations due to torrential rain and the fast-responding Weißeritz and Lockwitzbach streams occurred with high flow velocities and without any warning. In contrast, the water levels of the River Elber rose slowly and had been forecasted hours or days in advance. Damage cases in Dresden affected by the River Elber, the Weißeritz and the Lockwitzbach were investigated in this study. 


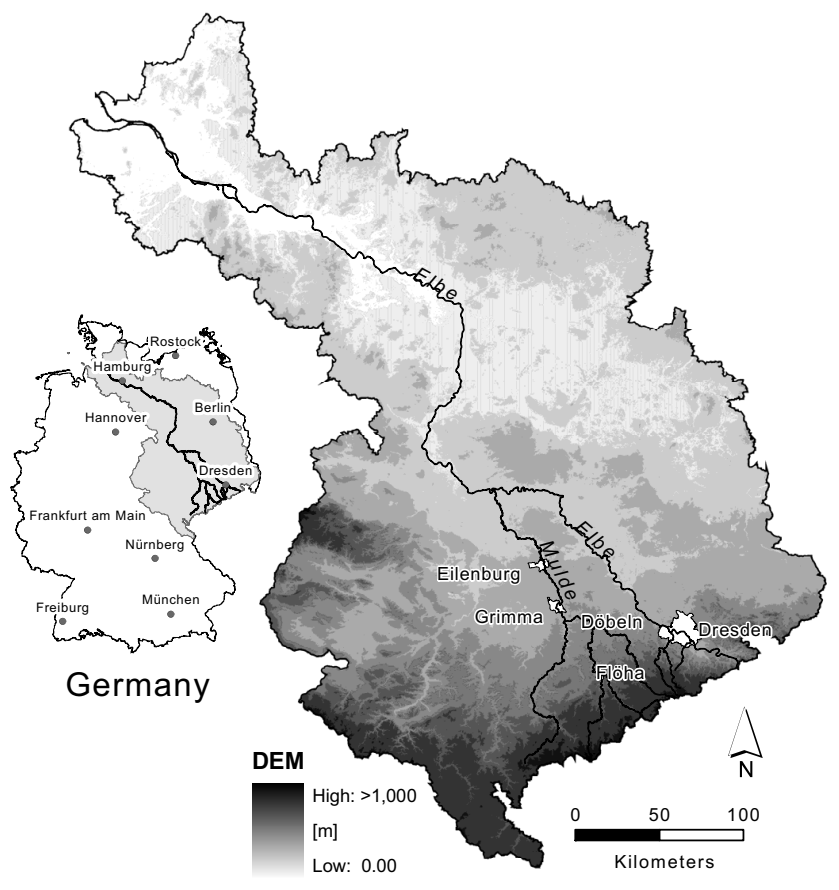

Fig. 1. Location of the five communities under study within the Elbe catchment.

Three communities under study, i.e. Grimma, Döbeln and Eilenburg, are located on the River Mulde. Flood events on the River Mulde have a flash flood character upstream, particularly in the upper part, e.g. at Döbeln and Grimma, and increasingly become riverine floods further downstream, e.g. at Eilenburg. In the cities along the River Mulde, inundation depths of up to $5 \mathrm{~m}$ and some very high velocities were witnessed in August 2002. A similar situation applies to the municipality of Flöha, which is located at the confluence of the Mulde's Flöha and Zschopau tributaries.

\subsection{Flood damage data}

An overview of the damage datasets used for this study is presented in Table 1. All datasets are related to the flood in 2002; detailed descriptions are given below.

Dataset R1 contains residential building damage data collected by experts in field surveys immediately after the August 2002 flood and data from questionnaires distributed to affected households in 2003 and 2004 (Schwarz et al., 2005). Damage cases are related to the building stock in Saxony, alongside the Mulde and Zschopau rivers. Dataset R1 contains detailed damage descriptions with respect to the observed structural and non-structural failure types, enabling refined classification of damage grades (see Table 4). As a consequence of case selection and responses to questionnaires distributed, particularly high damage grades are documented, which dominate the composition of this dataset. Besides information on the structural damage, dataset R1 also
Table 1. Overview of the damage datasets from the flood in 2002 used for this study.

\begin{tabular}{|c|c|c|c|c|c|c|c|}
\hline \multirow[b]{2}{*}{$\begin{array}{l}\text { Data } \\
\text { set }\end{array}$} & \multirow[b]{2}{*}{ Attributes } & \multicolumn{6}{|c|}{ Number of damage cases (in the test communities) } \\
\hline & & Dresden & Döbeln & Eilenburg & Flöha & Grimma & All \\
\hline $\mathrm{R} 1$ & $\begin{array}{l}\text { Structural } \\
\text { building } \\
\text { damage } \\
\text { [damage grade] }\end{array}$ & - & - & 254 & 43 & 42 & 339 \\
\hline $\mathrm{R} 2$ & $\begin{array}{l}\text { Absolute } \\
\text { residential } \\
\text { building loss [€] }\end{array}$ & 199 & 7 & 15 & 18 & 17 & 256 \\
\hline $\mathrm{R} 3$ & $\begin{array}{l}\text { Absolute } \\
\text { residential } \\
\text { building loss } \\
{[€]}\end{array}$ & - & 383 & 555 & - & 335 & 1273 \\
\hline \multirow[t]{2}{*}{ I1 } & $\begin{array}{l}\text { Structural } \\
\text { damage } \\
\text { to road } \\
\text { infrastructure } \\
\text { [damage grade] }\end{array}$ & 280 & - & - & - & - & 280 \\
\hline & $\begin{array}{l}\text { Absolute loss } \\
\text { to road } \\
\text { infrastructure } \\
{[€]}\end{array}$ & & & & & & \\
\hline \multirow[t]{7}{*}{$\mathrm{C} 1$} & $\begin{array}{l}\text { Absolute } \\
\text { commercial } \\
\text { building loss } \\
{[€]}\end{array}$ & 61 & 24 & 14 & 14 & 13 & 126 \\
\hline & $\begin{array}{l}\text { Absolute } \\
\text { equipment } \\
\text { loss }[€]\end{array}$ & & & & & & \\
\hline & $\begin{array}{l}\text { Absolute loss } \\
\text { to goods, } \\
\text { products, } \\
\text { stock [€] }\end{array}$ & & & & & & \\
\hline & $\begin{array}{l}\text { Absolute loss } \\
\text { to cars } \\
{[€]}\end{array}$ & & & & & & \\
\hline & $\begin{array}{l}\text { Business } \\
\text { interruption } \\
\text { loss [€] }\end{array}$ & & & & & & \\
\hline & $\begin{array}{l}\text { Business } \\
\text { interruption* } \\
\text { duration [days] }\end{array}$ & & & & & & \\
\hline & $\begin{array}{l}\text { Business } \\
\text { disruption** } \\
\text { duration [days] }\end{array}$ & & & & & & \\
\hline
\end{tabular}

* complete breakdown of business operations,

** partial breakdown of business operations.

includes information about water depth, duration, velocity (qualitatively, i.e. high, moderate or low) and other secondary, probably damage contributing, flood actions. However, only damage data from the Eilenburg, Grimma and Flöha study areas, which could be combined with flood impact parameters from hydraulic simulations, were used for the present analysis (Table 1).

Two independent datasets, R2 and R3, are available, providing data on absolute monetary residential building losses due to the flood in Germany in August 2002: dataset R2 was derived from computer-aided telephone interviews with flood affected private households, which were undertaken in the Elbe and Danube catchments in Germany in April and May 
2003 (Kreibich et al., 2005b; Thieken et al., 2005; 2007) and particularly in the city of Dresden in August and September 2007 (Kreibich et al., 2009). To record the absolute building loss, the following question was asked: "How much was the total loss to your building, if you sum up all the costs (material and labour) for all repair work necessary? The amount should be given in euro." The survey in the Elbe and Danube catchments resulted in 1697 completed interviews, the survey in the city of Dresden resulted in 454 completed interviews with affected private households. In our research areas, 256 records could be matched with the results of the hydraulic modelling (Table 1).

Dataset R3 was derived from a huge flood loss compensation programme coordinated by the Saxon Relief Bank (SAB). The SAB kept track of the repair works and costs due to the August 2002 flood as declared by the property owners, and their reconstruction aid. According to the flood loss compensation guidelines (SMI, 2002), costs for repairing or replacing damaged household contents and/or damaged outside facilities (fences, plants, etc.) were excluded from the compensation. Therefore, the eligible repair costs represent the total building damage. In the work of Kobsch (2005), data from SAB were combined with information about the building type, which was surveyed in the field. In our research areas, 1273 loss datasets could be connected to the results of the hydraulic modelling (Table 1).

Dataset I1 contains information on 280 inundated sections of the road infrastructure in a central part and in a suburban area of the City of Dresden. 147 inundated road sections were actually damaged. Due to the structure of the city, the length ( $30 \mathrm{~m}$ to $3 \mathrm{~km})$ and width ( $2.3 \mathrm{~m}$ to $15 \mathrm{~m})$ of the sections vary widely. The total length of the damaged road sections studied was $48.4 \mathrm{~km}$. The total repair costs amounted to 43.3 million $€$. In addition, dataset I1 contains the information for 133 inundated but undamaged road sections in these areas. The slow rising riverine flooding of the River Elbe occurred in both areas and in addition, the Weißeritz (city) and Lockwitz (suburb) streams flooded with higher velocities. Physical characteristics (length, width, sidewalks, etc.), the road classifications and some other features were documented for these 280 inundated road sections. The flood damage was recorded in two ways: (1) the absolute loss was derived from files in the city administration that contain the repair and reconstruction costs of all reconstruction projects after the 2002 flood. On the expectation that repair costs do not necessarily provide a good approximation of flood damage, (2) experts in the city administration were asked to rate the damage grade witnessed immediately after the flood on a six point scale, from $0=$ "no damage" to $5=$ "severe structural damage". Additionally, the experts rated the condition of the road before the flood on a five point scale, from $1=$ "very good" to $5=$ "very bad condition". For organisational reasons, the procedure for matching this dataset with the flood parameters differs from the general procedure applied in this study. Classified flood parameters related to the middle of each road section were appended to the data, i.e. water depth and flow velocity were originally recorded in categorical variables. To enable the calculation of combined parameters such as energy head; water depth and flow velocity were transformed back to the assumed discrete average values for the categories (Fig. 5).

Dataset $\mathrm{C} 1$ reflects flood damage to the commercial and industrial sector. It was derived from telephone interviews with flood affected companies held after the flood event in 2002. A detailed presentation of the whole survey is given by Kreibich et al. (2007). The dataset contains various information on different types of damage, e.g. absolute building loss, and duration of business interruption. In total, 415 companies in different economic sectors and of different sizes were interviewed in the Elbe catchment in Saxony, but only 126 damage cases could be matched with the results of the hydraulic modelling in our study areas (Table 1).

\subsection{Flood impact parameters from hydraulic simulations}

The hydraulic basis of this study is the flood simulations available from the flood protection concepts developed in Saxony following the severe flood in 2002 (SMUL-Sachsen, 2003). 2-D hydraulic simulations of the flood in 2002 (and for design floods with return periods of 20,50 and 100 years) were available for all areas under study (Table 2). These simulations were performed to calculate flooded areas and water depths as a basis for risk mapping and cost benefit analysis. The simulations also provided information on flow velocity, although this was not the focus of the modelling.

The 2-D hydraulic models were set up on grid cells ranging from $1 \times 1 \mathrm{~m}\left(1 \mathrm{~m}^{2}\right)$ to $25 \times 25 \mathrm{~m}\left(625 \mathrm{~m}^{2}\right)$, for which a mean water level and a mean depth-averaged flow velocity was calculated. These models generally provide specific results for the flow velocity. However, parameterisation of the built up areas is still decisive for the quality of the results (Apel et al., 2009). In many cases, especially where information on mean water levels and the extent of the flooded areas is mainly required, built up areas are parameterised with mean roughness coefficients (e.g. Bates and De Roo, 2000). This approach was followed in the Flöha case study. In other cases, buildings, streets, gardens etc. are explicitly considered in the model (e.g. Aronica et al., 1998) so that, for example, high flow velocities can occur in streets and no flow is simulated where buildings are located. This approach was applied in Grimma. It clearly leads to higher resolution and more realistic distribution of the calculated flow velocities, particularly in urban areas (Aronica and Lanza, 2005).

The impact parameters, water depth and flow velocity, were combined with the damage data via an intersection of the raster based data from hydraulic modelling with the (geocoded) single point objects of the damage datasets. A circular buffer with a $5 \mathrm{~m}$ radius was created around each damaged property to take into account data uncertainties such 
Table 2. Overview of available hydraulic simulations and their results in the study areas.

\begin{tabular}{|c|c|c|c|c|}
\hline $\begin{array}{l}\text { Study } \\
\text { area }\end{array}$ & Modelling approach & Grid size & $\begin{array}{l}\text { Water depth* } \\
{[\mathrm{m}]}\end{array}$ & $\begin{array}{l}\text { Flow velocity* } \\
{[\mathrm{m} / \mathrm{s}]}\end{array}$ \\
\hline Dresden & $\begin{array}{l}\text { 2-D simulation with a mean roughness coefficient for the built up area, } \\
\text { buildings with more than } 50 \mathrm{~m}^{2} \text { are modelled as no flow areas. } \\
\text { Detailed model (Finite Element Method) for the Weißeritz area. }\end{array}$ & $5 \times 5 \mathrm{~m}$ & Range: $0-10.6$ & Range: $0-3.0$ \\
\hline Döbeln & 2-D simulation with a mean roughness coefficient for the built up area. & $25 \times 25 \mathrm{~m}$ & Range: $0-6.3$ & Range: $0-1.4$ \\
\hline Eilenburg & 2-D simulation with a mean roughness coefficient for the built up area. & $25 \times 25 \mathrm{~m}$ & Range: $0-5.6$ & Range: $0-2.0$ \\
\hline Flöha & 2-D simulation with a mean roughness coefficient for the built up area. & $5 \times 5 \mathrm{~m}$ & Range: $0-1.3$ & Range: $0-1.0$ \\
\hline Grimma & 2-D simulation with a detailed modelling of streets and buildings. & $1 \times 1 \mathrm{~m}$ & Range: $0-4.6$ & Range: $0-2.9$ \\
\hline
\end{tabular}

* at the damage data points.

as locational inaccuracy of the damage data points resulting from geocoding procedures. The minimum, mean and maximum values of the water depths and flow velocities of all raster cells fully or partly within the buffer were determined and assigned to the damage record. Thus, impact parameters and damage data can be directly correlated. To obtain a comprehensive view of the influence of the flow velocity on the flood damage, not only the impact of flow velocity and water depth on the damage was investigated, but also combinations of these two factors. The physically based parameters energy head (Eq. 1), i.e. total energy according to the Bernoulli equation and an indicator for the flow force (Eq. 2) were selected. In flood situations, the energy head is highly dominated by water depth, whereas the indicator for flow force is more balanced and, particularly for low water depth, is often dominated by the flow velocity. Since intensity (Eq. 3) is widely accepted as a suitable indicator for the flood hazard and since it is predominantly used in all Saxon flood protection concepts (SFOWG et al., 1997; BWG, 2001; SMULSachsen, 2003), it was also selected here. These combined parameters were calculated using the following formulae:

Energy head $=h+v^{2} / 2 g$

Indicator for flow force $=h^{*} v^{2}$

Intensity $=v^{*} h$

with

$h$ : water depth $[\mathrm{m}]$

$v$ : flow velocity $[\mathrm{m} / \mathrm{s}]$

$g:$ acceleration of gravity $=9.81 \mathrm{~m} / \mathrm{s}^{2}$.

\section{Results and discussion}

\subsection{Flood impact characteristic in the study areas}

The flood impact characteristic at the damage data points within our study areas shows mean flow velocities up to $2 \mathrm{~m} / \mathrm{s}$ and mean water depth up to $6 \mathrm{~m}$ (Fig. 2). A rough comparison

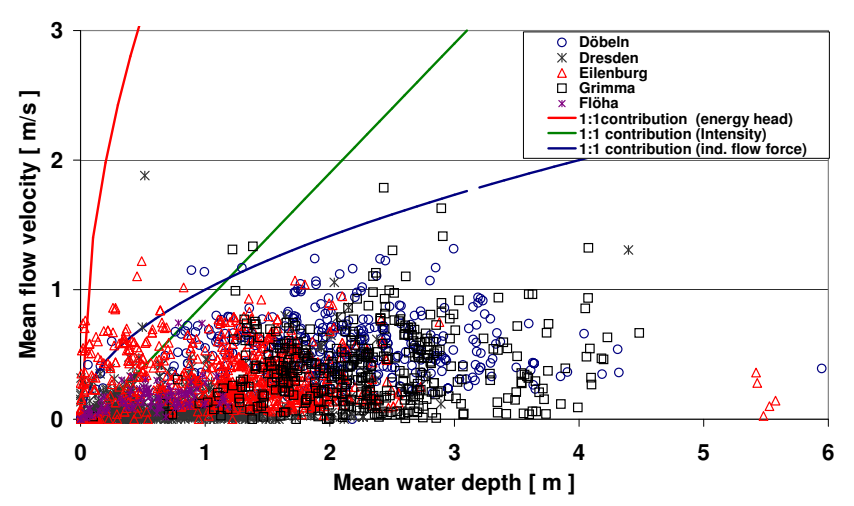

Fig. 2. Overview of the range of the mean water depths and the mean flow velocities extracted from the hydraulic models in a $5 \mathrm{~m}$ buffer around all damage data points within the study areas. In addition, the lines where the contribution of the flow velocity equals the contribution of water depth are shown for the three combined impact parameters.

of modelled and measured water depths in Dresden, Döbeln and Eilenburg suggests an overestimation of the maximum water levels by the hydraulic models. Most maximum flow velocities are within the range of $0-0.5 \mathrm{~m} / \mathrm{s}$ (Fig. 3). Only data from Grimma, Döbeln and partly Eilenburg show a significant amount of maximum flow velocities in the range of $0.6-1.0 \mathrm{~m} / \mathrm{s}$ and only in Grimma is the maximum flow velocity within the range between $1.1-1.5 \mathrm{~m} / \mathrm{s}$ in more than $10 \%$ of the damage cases. This is mainly due to the more detailed hydraulic modelling, taking into account streets and buildings. This hydraulic approach leads to significant differences between the mean and maximum flow velocities within the $5 \mathrm{~m}$ buffers around the damaged structures and buildings. Due to the more detailed modelling of streets and houses, the maximum flow velocities are significantly shifted to higher velocity classes in Grimma, in contrast to the simulation results in the other study areas (Fig. 3). Therefore, an underestimation of the actual maximum flow velocities during the flood events has to be assumed for most study areas due to the hydraulic approach used. 

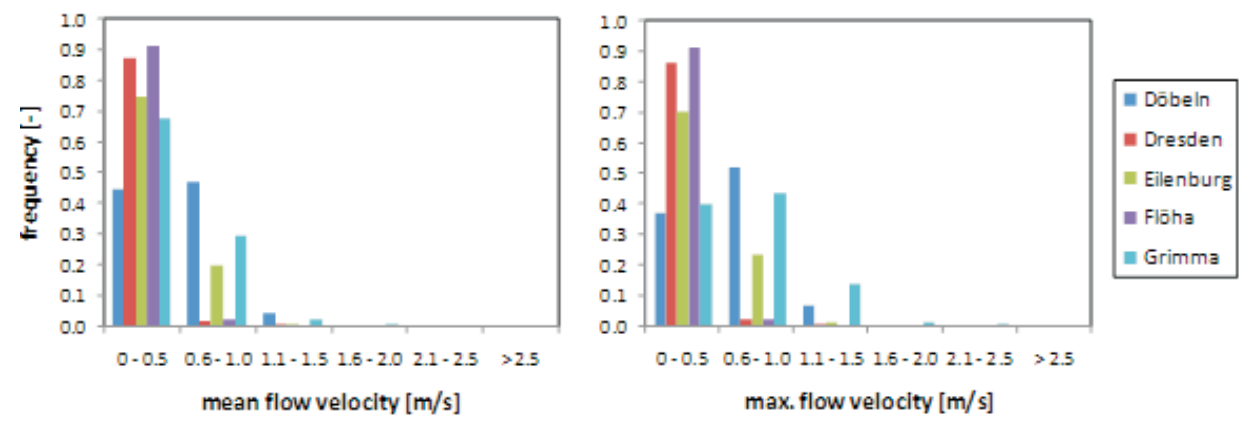

Fig. 3. Frequency of flow velocities (left: mean values, right: maximum values) extracted from the hydraulic models in a $5 \mathrm{~m}$ buffer around all damage data points within the study areas.

The energy head, i.e. the total mechanical energy (kinetic and potential), is highly dominated by the potential energy, i.e. the water depth. The red line in Fig. 2 indicates the 50\% line, at which the contribution of the flow velocity equals the contribution of the water depth to the energy head. In $1 \%$ of the cases, in situations with very low water depth, the flow velocity dominates the energy head (Fig. 2). The contribution of the flow velocity and the water depth to the indicator for flow force (blue line) and intensity (green line) is slightly more balanced (Fig. 2). Flow velocity dominates the indicator for flow force in $4 \%$ of the cases, and it dominates the intensity in $7 \%$ of the cases. This is the case particularly in situations with water depths below $1 \mathrm{~m}$ in the cities of Eilenburg and Dresden. However, both parameters are dominated by water depth in all cases with water depths above $2.5 \mathrm{~m}$ (Fig. 2). These dependencies between the impact parameters are also confirmed by their correlations (Table 3 ).

\subsection{Flood impact parameters and structural damage}

\subsubsection{Structural damage of residential buildings}

Analogous to the empirical, intensity-oriented method introduced by the Earthquake Damage Analysis Center (EDAC) for earthquake damage and loss modelling, characteristic flood vulnerability classes were determined for the different building types (Schwarz and Maiwald, 2007, 2008). The main focus was on consideration of structural damage due to flood impact. Following the definition of earthquake-caused damage grade in the European Macroseismic Scale EMS-98 (Grünthal et al., 1998), structural and non-structural damage indicators, which can be repeatedly observed, were distinguished. Characteristic descriptive indicators were assigned to each damage grade. Five damage grades $\left(D_{i} ; i=1\right.$ to 5$)$ are classified in order of increasing flood impact (cf. Table 4, Schwarz and Maiwald, 2007, 2008).

The schema in Table 4 was applied to each record within dataset R1, i.e. the available descriptions of observed flood effects were re-evaluated and assigned to the most likely damage grade $D_{i}(i=1$ to 5$)$ in a uniform way. The distri-
Table 3. Rank correlation (Spearman's rho) between the impact parameters (all coefficients are significant at the 0.01 level (two-sided); n=2499).

\begin{tabular}{|c|c|c|c|c|c|}
\hline & $\begin{array}{l}\text { Flow } \\
\text { velocity } \\
\text { (mean) } \\
{[\mathrm{m} / \mathrm{s}]}\end{array}$ & $\begin{array}{l}\text { Water } \\
\text { depth } \\
\text { (mean) } \\
{[\mathrm{m}]}\end{array}$ & $\begin{array}{l}\text { Energy } \\
\text { head } \\
\text { (mean) } \\
{[\mathrm{m}]}\end{array}$ & $\begin{array}{l}\text { Indicator for } \\
\text { flow force } \\
(\text { mean) } \\
{\left[\mathrm{m}^{3} / \mathrm{s}^{2}\right]}\end{array}$ & $\begin{array}{l}\text { Intensity } \\
\text { (mean) } \\
{\left[\mathrm{m}^{2} / \mathrm{s}\right]}\end{array}$ \\
\hline $\begin{array}{l}\text { Flow velocity } \\
\text { (mean) }[\mathrm{m} / \mathrm{s}]\end{array}$ & 1.00 & 0.46 & 0.47 & 0.94 & 0.88 \\
\hline $\begin{array}{l}\text { Water depth } \\
\text { (mean) }[\mathrm{m}]\end{array}$ & & 1.00 & 1.00 & 0.68 & 0.78 \\
\hline $\begin{array}{l}\text { Energy head } \\
\text { (mean) }[\mathrm{m}]\end{array}$ & & & 1.00 & 0.69 & 0.79 \\
\hline $\begin{array}{l}\text { Indicator for } \\
\text { flow force } \\
(\text { mean })\left[\mathrm{m}^{3} / \mathrm{s}^{2}\right]\end{array}$ & & & & 1.00 & 0.99 \\
\hline $\begin{array}{l}\text { Intensity } \\
(\text { mean })\left[\mathrm{m}^{2} / \mathrm{s}\right]\end{array}$ & & & & & 1.00 \\
\hline
\end{tabular}

bution of the individual damage grades within dataset $\mathrm{R} 1$ is shown in Table 5. Flood impact parameters (water depth, flow velocity etc.) can be correlated with the damage grades, enabling direct derivation of a new set of damage functions (cf. Schwarz and Maiwald, 2008).

Due to the limited amount of damage data in dataset R1, the impact of flow velocity on the damage grade is studied without further differentiation and subdivision of the building types. Nevertheless, previous studies by Maiwald (2007) and Schwarz and Maiwald (2007) indicate that a more refined level of consideration is advantageous. Using a rank correlation (Spearman's rho) between impact parameters and damage grades, the following conclusions can be derived from dataset R1 (Table 6):

- The impact of flow velocity on the extent of structural damage is not independent of water depth. Flow velocity alone shows no significant correlation with the damage grade. 
Table 4. Assignment of damage grade $D_{i}$ to damage cases (Schwarz and Maiwald, 2007, 2008).

\begin{tabular}{|c|c|c|c|c|c|}
\hline \multirow{2}{*}{$D_{i}$} & \multicolumn{2}{|c|}{ Damage } & \multirow{2}{*}{ Description } & \multirow{2}{*}{ Drawing } & \multirow{2}{*}{ Example } \\
\hline & Structural & Non-structural & & & \\
\hline$D_{1}$ & no & slight & penetration and pollution only & & \\
\hline$D_{2}$ & $\begin{array}{l}\text { no to } \\
\text { slight }\end{array}$ & moderate & $\begin{array}{l}\text { slight cracks in load-bearing members broken } \\
\text { doors and windows contamination } \\
\text { replacement of extension elements }\end{array}$ & & \\
\hline$D_{3}$ & moderate & heavy & $\begin{array}{l}\text { major cracks and/or deformations in } \\
\text { load-bearing walls and slabs settlement } \\
\text { replacement of non-load bearing elements }\end{array}$ & & \\
\hline$D_{4}$ & heavy & $\begin{array}{l}\text { very } \\
\text { heavy }\end{array}$ & $\begin{array}{l}\text { structural collapse of load-bearing walls, } \\
\text { slabs replacement of load-bearing elements }\end{array}$ & & \\
\hline$D_{5}$ & $\begin{array}{l}\text { very } \\
\text { heavy }\end{array}$ & $\begin{array}{l}\text { very } \\
\text { heavy }\end{array}$ & $\begin{array}{l}\text { collapse of the building or of major parts } \\
\text { of the building demolition of building required }\end{array}$ & & \\
\hline
\end{tabular}

- The water depth and the energy head show comparable correlations with structural damage, which was most highly correlated with the means of the impact parameters.

- With regard to the indicator for flow force and flood intensity, only weak correlations exist between the damage grades and the mean impact parameters. No significant correlations are apparent for the minimum parameters.

The influence of the mean impact parameters on the damage grade of dataset R1 is illustrated in Fig. 4. It becomes evident that in cases of lower values on the impact side, the damage grade remains unaffected and is slightly scattered around damage grade $D_{2}$. Moderate or heavy structural damage (damage grade $D_{3}$ and higher) occurred only in cases with a very high level of flood impact. A significant increase in the mean damage grade $D_{m}$ is apparent at a water depth above $2 \mathrm{~m}$, an energy head above $2 \mathrm{~m}$, an indicator for flow force above $2 \mathrm{~m}^{3} / \mathrm{s}^{2}$ and intensity above $1.5 \mathrm{~m}^{2} / \mathrm{s}$ (Fig. 4). Thus, a critical lower impact parameter bound may be defined for the occurrence of severe structural damage. Claußen and Clark (1990) concluded from a histor- ical database (Harrison, 1864) and only considering the flood intensity $\left(v_{f l} \times h\right)$ that such a critical level is given for a flow velocity of $2.0 \mathrm{~m} / \mathrm{s}$. Below this value collapse is not to be expected. Smith (1991) found a similar criterion for the failure of masonry and concrete buildings. Dataset R1 contains a number of damage cases where damage grade $D_{4}$ and $D_{5}$ was observed for flow velocities $v_{f l}<2.0 \mathrm{~m} / \mathrm{s}$ (Fig. 4). On the one hand, there is a possibility that the hydraulic simulation has underestimated the flow velocity and assignment of the calculated flow velocities to the damage cases is inaccurate. On the other hand, the observations can be explained by the different vulnerability of the building types, i.e. vulnerable building types such as clay structures will suffer serious damage under a lower impact level. Thus, the definition of such critical impact levels should be undertaken separately for different building types.

Only a minor impact of flow velocity on structural damage to residential buildings could be demonstrated on the basis of the available data. However, structural damage to buildings due to floods is always the consequence of both water depth and flow velocity. Therefore, the energy head appears to be a suitable flood impact parameter for reliable forecasting of structural damage (cf. Schwarz and Maiwald, 2008). Further 
Table 5. Distribution of damage grades in dataset R1.

\begin{tabular}{llllll}
\hline Damage grade & $D_{1}$ & $D_{2}$ & $D_{3}$ & $D_{4}$ & $D_{5}$ \\
No. of damage cases & 8 & 270 & 31 & 14 & 16 \\
\hline
\end{tabular}

research on the basis of a larger database, including significantly more cases with larger flow velocities, is required to enable a detailed definition of critical impact levels and clear identification of the impact of flow velocity.

\subsubsection{Structural damage of road infrastructure}

Flood impact on the road infrastructure was studied by considering the water depth, the flow velocity, the energy head, the indicator for flow force and the intensity. Only the data from the inner city of Dresden that was affected by inundation of the River Elber and the Weißeritz are studied here (134 road sections, 70 of which were damaged). The distributions of some relevant variables of the road damage data of dataset I1 are given in Table 7. Damage grade versus flow velocities is visualised in a scatter plot (Fig. 5).

The rank correlation of all three impact parameters with damage grade is significant and greatest for flow velocity (Table 6). To find a parametric model for the structural damage of the roads, ordered probit models, which fit an ordinal dependent variable (damage grade) of the independent variables (impact parameters) were used (Stata, 2007). Testing the impact of each flood parameter alone on damage grade yielded models where the coefficients have the correct sign, are significant and a noteworthy part of the variation in data is explained. Table 8 presents the estimated coefficients (in the units of the respective impact parameter) for the four single variable models along with relevant statistics. In these singlevariable models the flow velocity and the intensity explained the structural damage better than either water depth or energy head, as judged by coefficient, significance and pseudo r-square. The performance of the models could not be improved by combining the impact parameters in any way. The best models, explaining the structural damage alone on basis of the flow velocity or the intensity are included in Table 8 .

It was further hypothesised that the flood damage to roads may also depend on the road classification, since it reflects characteristics of the road design. For instance, a main arterial road has more substantial cross-sectional elements (surface, backfill, etc.) than a low-volume feeder road. Another variable that potentially modifies the impact of the flood is the road maintenance condition before the flood, assuming that a well maintained road is less vulnerable. However, in dataset I1 road class and road condition before the flood were highly correlated, since higher class roads are better maintained. Road class and flow velocity were also correlated, as in this particular setting it happened that higher class roads were subjected to higher flow velocities. Therefore, the effects of these independent variables could not be disentangled. Further studies of how road type and road condition influence flood damage are necessary.

For the flood damage to roads, this study presents initial results establishing flow velocity as a key parameter for the estimation of structural damage based on the analysis of individual road sections. However, although flow velocity is a significant predictor for damage to a road, there is neither a clear nor a very strong relationship (Fig. 5). Thus, given the empirical setting, this does not provide a transferable model ready for use in predictions as other types of floods in other areas need to be studied first.

\subsection{Impact parameters and absolute monetary loss}

\subsubsection{Absolute monetary loss to residential buildings}

Significant correlations between the absolute building losses and the flow velocity are scarce and in general are comparatively low (Table 6). Only the loss data of set R2 shows significant, but very weak correlations of 0.15 and 0.13 with the minimum and maximum flow velocity data respectively. In contrast, the absolute building losses of the two datasets show significant correlations with all water depth and energy head data (minimum, mean and maximum values; Table 6). The loss data of set R2 also shows significant correlations with the minimum, mean and maximum indicator for flow force and the intensities (Table 6). This is in contrast to the loss data of set R3 which shows only significant but very weak correlations with the maximum values of the indicator for flow force and intensity.

Of course, the general picture is similar to the loss data grouped into impact parameter classes (Fig. 6). There was either no significant difference in the losses between the mean flow velocity classes (dataset R2). Or the losses tend to decrease with increasing flow velocity classes (dataset R3), which is unrealistic and points to hidden factors influencing the losses. In contrast, building losses of both datasets are significantly different between the water level and energy head classes and mean losses (as well as medians) increase with increasing flood impact (Fig. 6). No significant differences in building losses were observed between the classes for the indicator for flow force and the intensity. Other factors apparently have a far greater influence on the monetary flood loss of residential buildings than flow velocity. For instance, significant loss reduction can be achieved by early warning (Smith, 1981; Penning-Rowsell and Green, 2000), flood experience (Wind et al., 1999) or private preventive measures (ICPR, 2002; Kreibich et al., 2005b). 
Table 6. Rank correlations (Spearman's rho) between impact parameters and damage types (*coefficients significant at the 0.05 level).

\begin{tabular}{|c|c|c|c|c|c|c|c|}
\hline \multirow[b]{2}{*}{ impact parameters } & & \multicolumn{2}{|c|}{ structural damage } & \multicolumn{2}{|c|}{ monetary damage } & \multicolumn{2}{|c|}{ indirect damage } \\
\hline & & $\begin{array}{l}\text { damage } \\
\text { grade of } \\
\text { residential } \\
\text { buildings } \\
\text { [-] } \\
\text { (dataset R1) }\end{array}$ & $\begin{array}{l}\text { damage } \\
\text { grade of } \\
\text { road infra- } \\
\text { structure } \\
{[-]} \\
\text { (dataset I1) }\end{array}$ & $\begin{array}{l}\text { absolute } \\
\text { loss of } \\
\text { residential } \\
\text { buildings } \\
{[€]} \\
\text { (dataset R2) }\end{array}$ & $\begin{array}{l}\text { absolute } \\
\text { loss of } \\
\text { residential } \\
\text { buildings } \\
{[€]} \\
\text { (dataset R3) }\end{array}$ & $\begin{array}{l}\text { business } \\
\text { interruption } \\
\text { duration } \\
\text { [d] } \\
\text { (dataset C1) }\end{array}$ & $\begin{array}{l}\text { business } \\
\text { disruption } \\
\text { duration } \\
\text { [d] } \\
\text { (dataset C1) }\end{array}$ \\
\hline flow velocity $[\mathrm{m} / \mathrm{s}]$ & $\begin{array}{l}\text { minimum } \\
\text { mean } \\
\text { maximum }\end{array}$ & $\begin{array}{r}-0.10 \\
-0.00 \\
0.04\end{array}$ & $0.31^{*}$ & $\begin{array}{l}0.15^{*} \\
0.09 \\
0.13^{*}\end{array}$ & $\begin{array}{r}-0.03 \\
-0.01 \\
0.03\end{array}$ & $\begin{array}{r}-0.01 \\
0.15 \\
0.12\end{array}$ & $\begin{array}{l}0.03 \\
0.10 \\
0.16\end{array}$ \\
\hline water depth [m] & $\begin{array}{l}\text { minimum } \\
\text { mean } \\
\text { maximum }\end{array}$ & $\begin{array}{l}0.23^{*} \\
0.34^{*} \\
0.24^{*}\end{array}$ & $0.22^{*}$ & $\begin{array}{l}0.28^{*} \\
0.32^{*} \\
0.33^{*}\end{array}$ & $\begin{array}{l}0.12^{*} \\
0.16^{*} \\
0.15^{*}\end{array}$ & $\begin{array}{l}0.27^{*} \\
0.15 \\
0.21\end{array}$ & $\begin{array}{l}0.36^{*} \\
0.23^{*} \\
0.36^{*}\end{array}$ \\
\hline energy head [m] & $\begin{array}{l}\text { minimum } \\
\text { mean } \\
\text { maximum }\end{array}$ & $\begin{array}{l}0.23^{*} \\
0.34^{*} \\
0.25^{*}\end{array}$ & $0.25^{*}$ & $\begin{array}{l}0.28^{*} \\
0.32^{*} \\
0.33^{*}\end{array}$ & $\begin{array}{l}0.12^{*} \\
0.15^{*} \\
0.15^{*}\end{array}$ & $\begin{array}{l}0.17 \\
0.16 \\
0.21^{*}\end{array}$ & $\begin{array}{l}0.20 \\
0.23^{*} \\
0.26^{*}\end{array}$ \\
\hline $\begin{array}{l}\text { indicator for } \\
\text { flow force } \\
{\left[\mathrm{m}^{3} / \mathrm{s}^{2}\right]}\end{array}$ & $\begin{array}{l}\text { minimum } \\
\text { mean } \\
\text { maximum }\end{array}$ & $\begin{array}{c}-0.05 \\
0.10^{*} \\
0.05\end{array}$ & $0.31^{*}$ & $\begin{array}{l}0.20^{*} \\
0.19^{*} \\
0.21^{*}\end{array}$ & $\begin{array}{l}0.00 \\
0.02 \\
0.07^{*}\end{array}$ & $\begin{array}{l}0.10 \\
0.17 \\
0.14\end{array}$ & $\begin{array}{l}0.18 \\
0.17 \\
0.24\end{array}$ \\
\hline intensity $\left[\mathrm{m}^{2} / \mathrm{s}\right]$ & $\begin{array}{l}\text { minimum } \\
\text { mean } \\
\text { maximum }\end{array}$ & $\begin{array}{r}-0.00 \\
0.16^{*} \\
0.10^{*}\end{array}$ & $0.29^{*}$ & $\begin{array}{l}0.23^{*} \\
0.24^{*} \\
0.27^{*}\end{array}$ & $\begin{array}{l}0.02 \\
0.05 \\
0.09^{*}\end{array}$ & $\begin{array}{l}0.13 \\
0.18 \\
0.23^{*}\end{array}$ & $\begin{array}{l}0.17 \\
0.20^{*} \\
0.24^{*}\end{array}$ \\
\hline
\end{tabular}

\subsubsection{Absolute monetary loss to road infrastructure and companies}

The total loss for the 147 damaged sections of roads in Dresden amounted to 43.3 million $€$ with average repair costs of 0.9 million $€$ per $\mathrm{km}$ or close to $90 €$ per $\mathrm{m}^{2}$. Sidewalks and other adjacent surfaces had repair costs nearly half that amount. For almost half the damaged road sections, the recorded repair costs were at or above the estimated total replacement costs for the particular kind of road, and in some instances were substantially above. This reflects the common practice in infrastructure reconstruction projects to not only repair the damage but also to renew and upgrade the infrastructure to meet current standards. Therefore, it is not surprising that no significant correlations or models could be found for the absolute monetary losses of road infrastructure in relation to the impact parameters.

A similar result has to be reported for the absolute monetary losses of companies. No significant correlations with any of the impact parameters analysed existed for any of the monetary loss types recorded in dataset $\mathrm{C} 1$, i.e. building loss, equipment loss, loss to goods, products, stock and loss to cars. One reason is certainly the high heterogeneity of companies, which necessitates quite detailed, separate analyses for each sector (Kreibich et al., 2007), but not possible here due to the limited amount of damage data.
Table 7. Overview of selected variables of the road damage data of dataset I1 (city).

\begin{tabular}{lllllll}
\hline Variable & Explanation & Obs & Mean & Std. Dev. & Min & Max \\
\hline Damage grade & expert damage rating & 134 & 1.54 & 1.80 & 0 & 5 \\
Road condition & expert condition rating & 124 & 2.71 & 1.32 & 1 & 5 \\
Water depth & water depth m & 134 & 0.76 & 0.63 & 0 & 2.5 \\
Flow velocity & water velocity m/s & 134 & 0.63 & 0.69 & 0 & 2.5 \\
eh & energy head m & 134 & 0.81 & 0.66 & 0 & 2.82 \\
$I$ & intensity $\mathrm{m}^{2} / \mathrm{s}$ & 134 & 0.63 & 1.13 & 0 & 6.25 \\
\hline
\end{tabular}

Table 8. Single variable probit models for damage grade of roads.

\begin{tabular}{lccccc}
\hline $\begin{array}{l}\text { Impact } \\
\text { parameter }\end{array}$ & Coef. & Std. Err. & $z$ & $\begin{array}{c}\text { Number of obs }=134 \\
P>z\end{array}$ & Pseudo R2 \\
& & & & & \\
\hline Flow velocity & 0.72 & 0.15 & 4.81 & 0.000 & 0.053 \\
Water depth & 0.41 & 0.15 & 2.66 & 0.008 & 0.016 \\
Energy head & 0.47 & 0.15 & 3.17 & 0.002 & 0.023 \\
Intensity & 0.50 & 0.11 & 4.48 & 0.000 & 0.058 \\
\hline
\end{tabular}



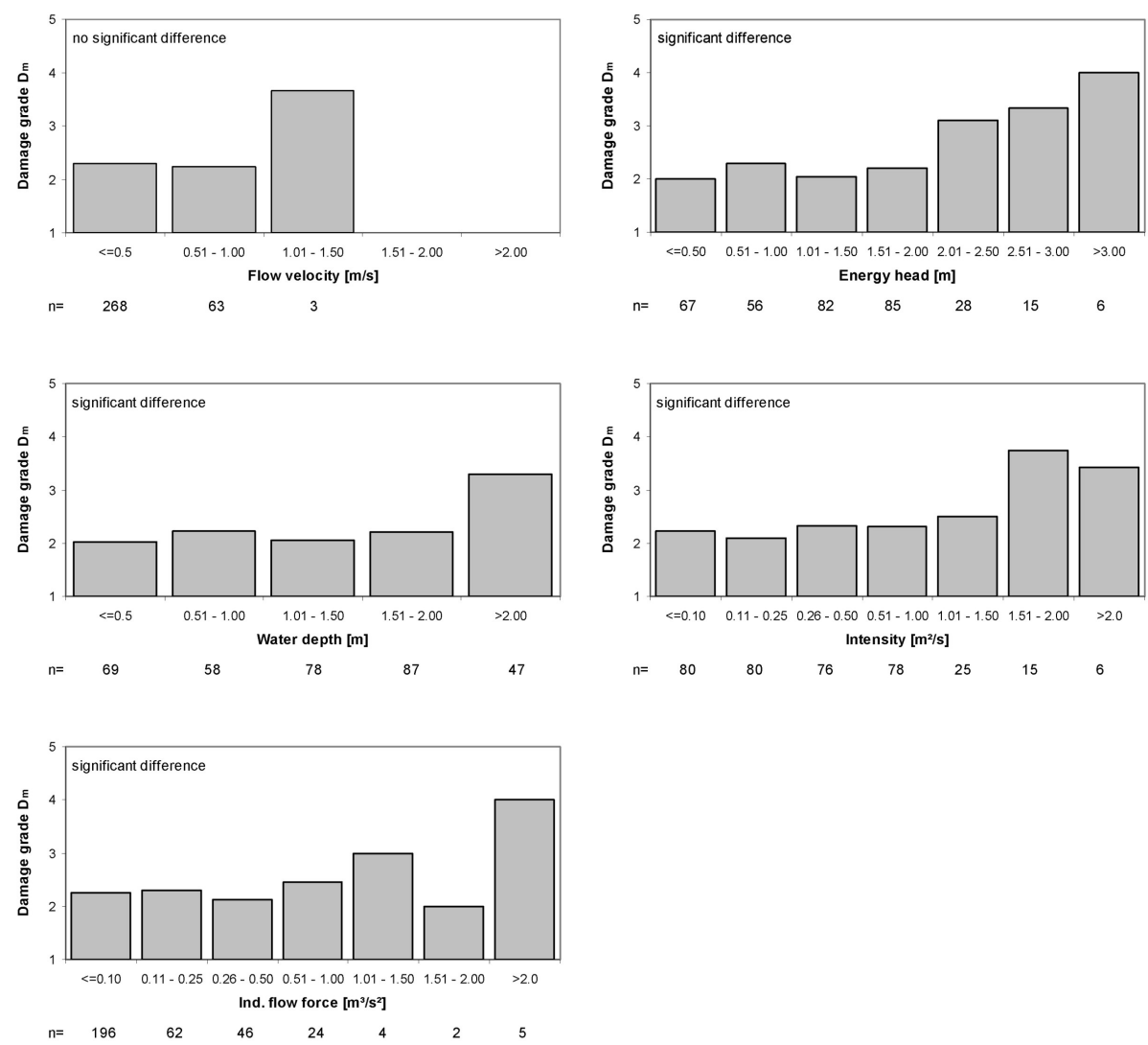

Fig. 4. The influence of the mean impact parameters flow velocity, water depth, energy head, indicator for flow force and intensity on the damage grade of dataset R1 (bars = means, significant differences are indicated at the $p<0.05$ level).

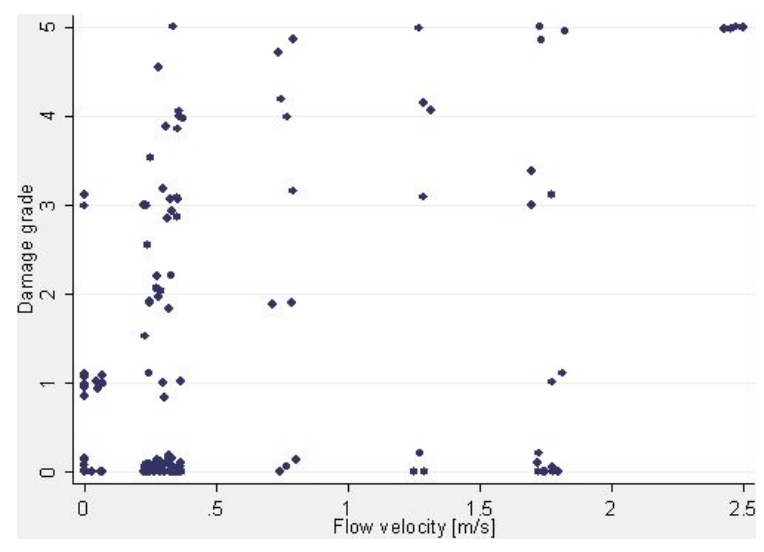

Fig. 5. Flow velocity and damage grade of the road infrastructure in the inner city of Dresden, affected by the Elbe and Weißeritz flood in August 2002.

\subsection{Impact parameters and business interruption and disruption duration}

Flow velocity does not have any significant correlations with business interruption or with business disruption duration
(Table 6). Business interruption duration only shows significant correlations with the minimum water depth, the maximum energy head and the maximum intensity. Business disruption duration shows more significant correlations: with water depth (minimum, mean and maximum values), energy head and intensity (mean and maximum values). Therefore, business disruption duration is analyzed in-depth. Plotting business disruption duration against the classified impact parameters reveals that there is no clear apparent increase in business disruption duration with increasing impact for any of the impact parameters (Fig. 7). The sudden changes of increase and decrease from one class of impact parameter to the next indicates that not only the examined impact parameters, but other factors not considered in this analysis, might also influence business disruption duration. For instance, significant differences concerning the business sector were found for the shown water depth classes as well as for the energy head classes (results not shown). The importance of the different sectors for damage analysis of companies has already been shown, e.g. by Kreibich et al. (2007). 
Data set R2
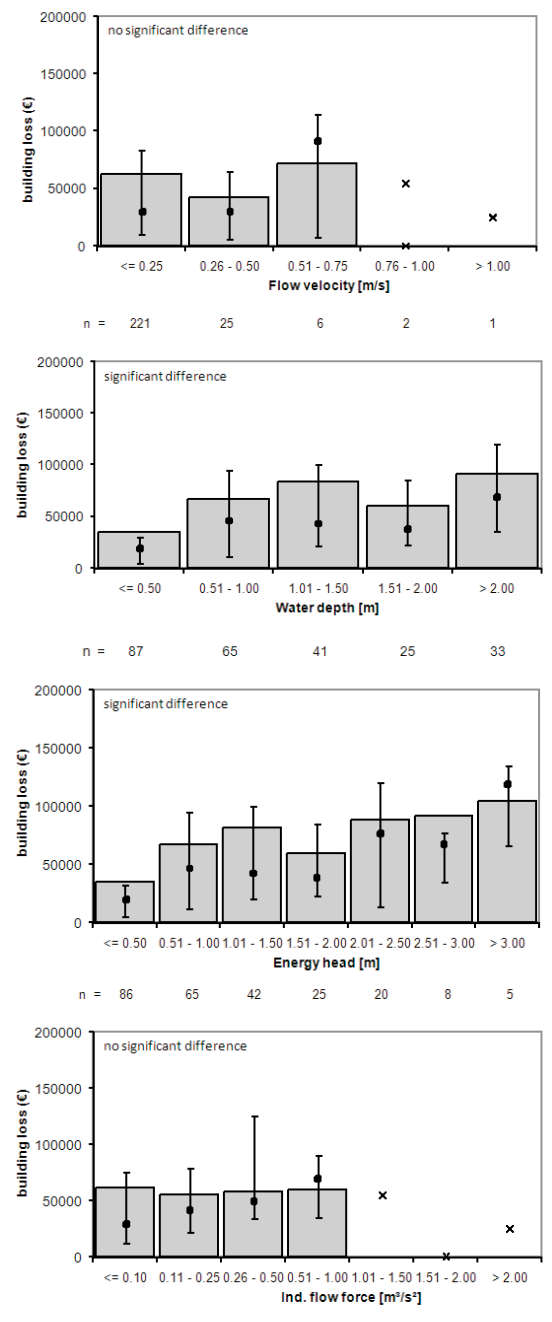

$n=223 \quad 15 \quad 4$

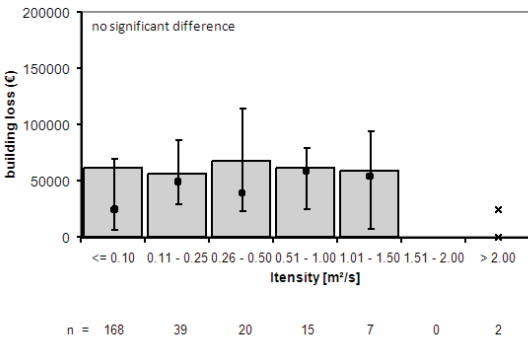

Data set R3
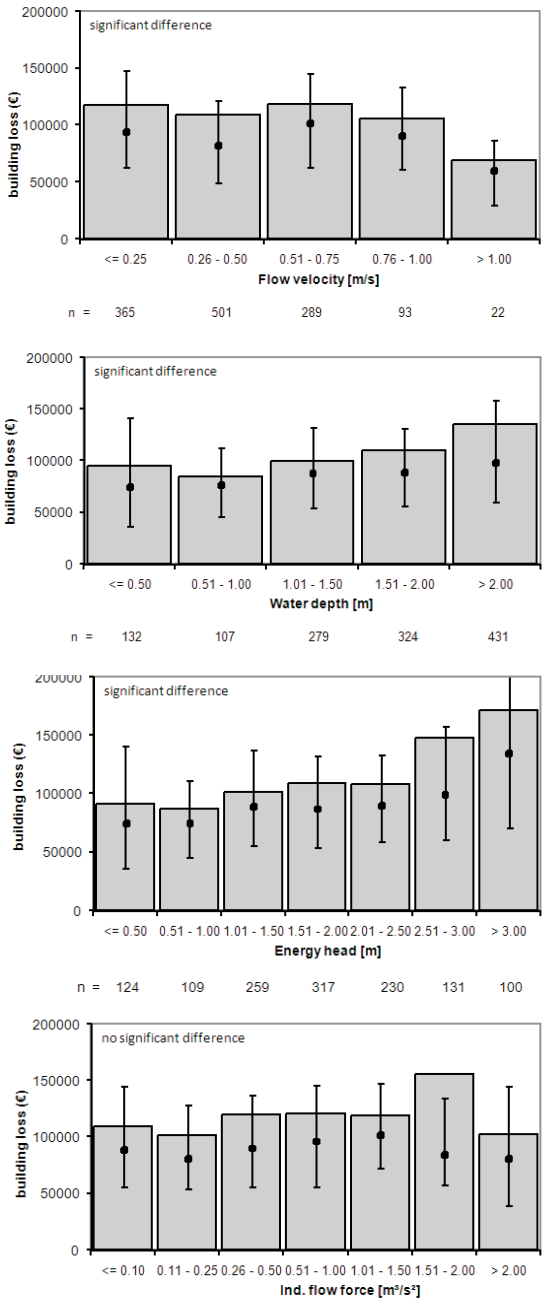

$n=418 \quad 290 \quad 200 \quad 219 \quad 75 \quad 34 \quad 34$

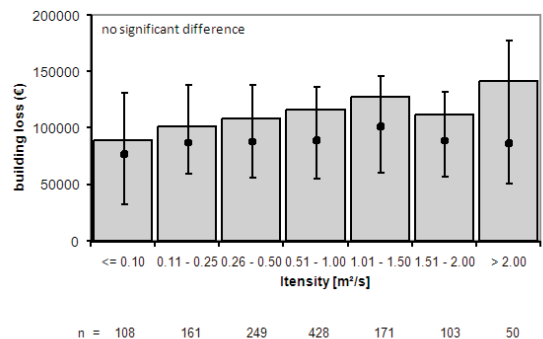

Fig. 6. The influence of the mean impact parameters flow velocity, water depth, energy head, indicator for flow force and intensity on the residential building losses of datasets R2 (left) and R3 (right) (bars = means, points = medians and 25-75\% percentiles, $x=$ single values; significant differences are indicated at the $p<0.05$ level).

\section{Conclusions}

A strong influence of flow velocity on flood damage could only be identified for structural damage of road infrastructure (Fig. 8). Further, a significant influence of flow velocity on the structural damage of residential buildings is suspected for flow velocities above a certain critical lower bound analogous to the other impact parameters. However, further research on the basis of a larger database, including significantly more cases with higher flow velocities, is required to test this hypothesis. In contrast, the influence of flow velocity on monetary losses of residential buildings, companies 

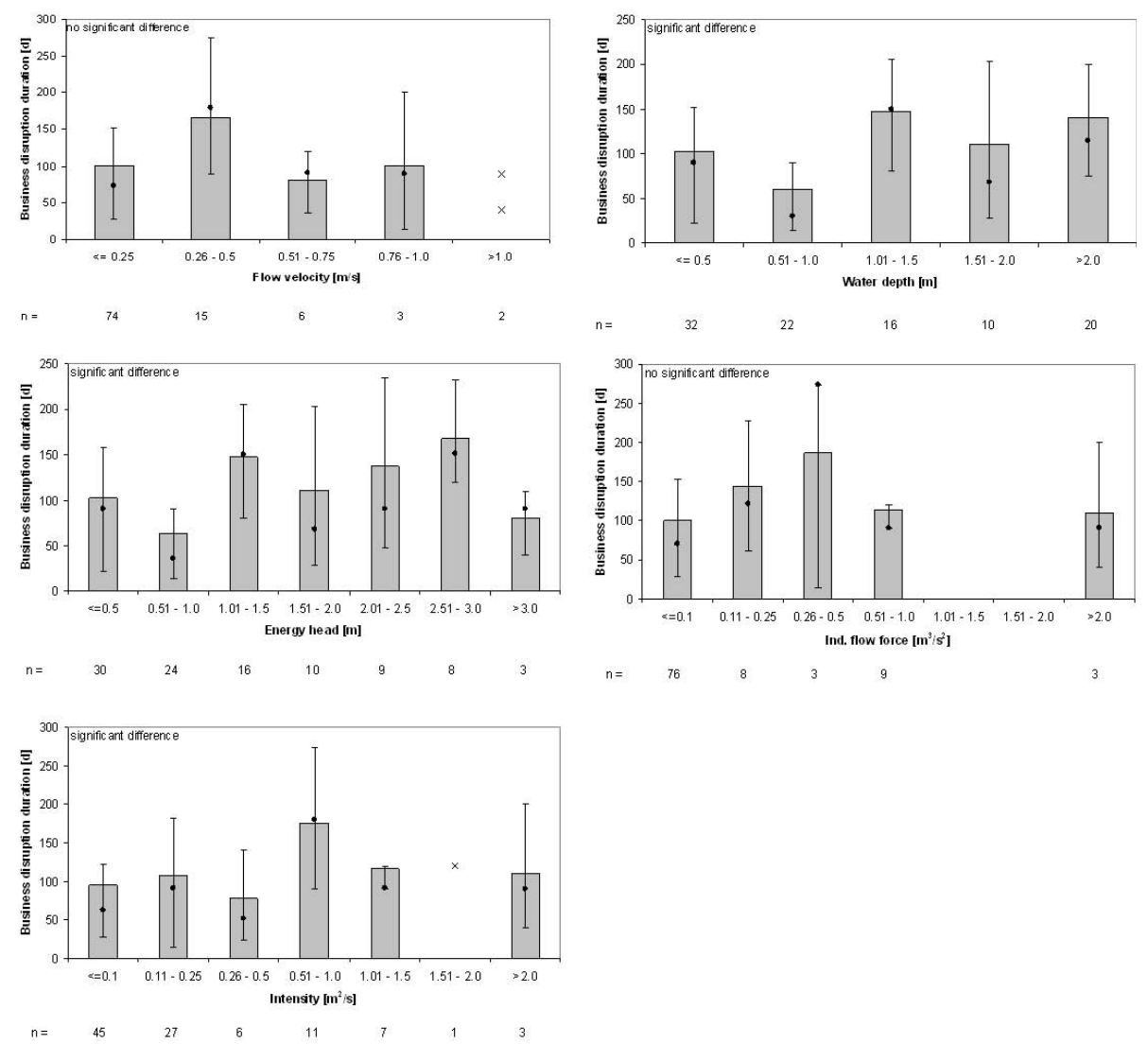

Fig. 7. The influence of the mean impact parameters flow velocity, water depth, energy head, indicator for flow force and intensity on business disruption duration (bars $=$ means, points $=$ medians and $25-75 \%$ percentiles, $x=$ single values; significant differences are indicated at the $p<0.05$ level).

and road infrastructure, as well as on business interruption/disruption duration was weak to non-existent (Fig. 8). The water depth and the energy head, which are highly correlated, have a medium to strong influence on all investigated damage types, except on monetary losses of companies and road infrastructure. Thus, the energy head is suggested as a suitable flood impact parameter for reliable forecasting of structural damage to residential buildings above a critical impact level of $2 \mathrm{~m}$ of energy head or water depth. Forecasting of structural damage to road infrastructure should be based on the flow velocity alone. Water depth is an important parameter for monetary loss estimation as it is commonly used in loss modelling. General consideration of flow velocity in monetary loss modelling cannot be recommended on the basis of this study. Damage modelling for companies needs a more detailed approach, at least differentiating them according to economic sectors.

However, further research is necessary to verify these results. Further studies should either focus on single cases affected by a high flow velocity or use a database with significantly more damage cases affected by high flow velocities. Additionally, more homogenous and better hydraulic simulations should be used, since very detailed hydraulic models

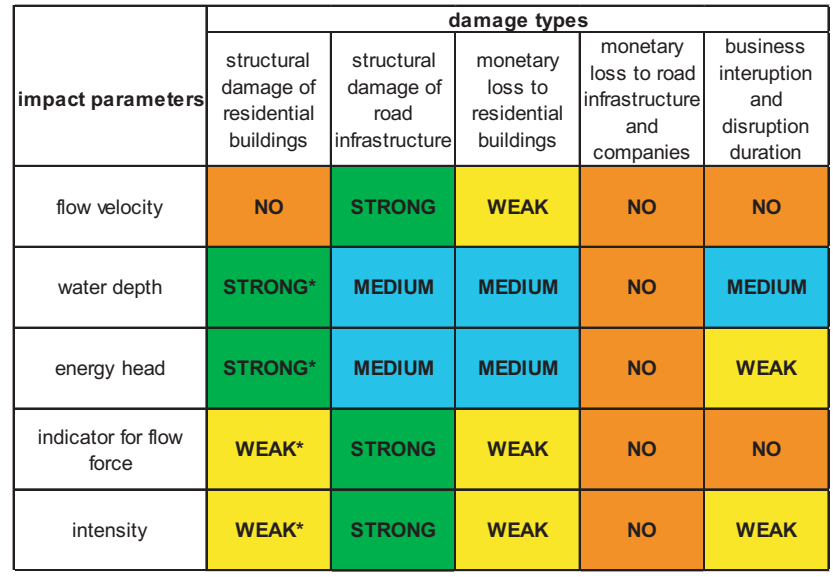

Fig. 8. Qualitative summary of the influence of impact parameters on flood damage.

(2-D or physical models) with high spatial resolutions are necessary to obtain the required information on the local flow characteristics. 
Acknowledgements. This research was funded by the German Ministry of Education and Research (BMBF) within the framework of the MEDIS - Methods for the Evaluation of Direct and Indirect Flood Losses project (No. 0330688). The survey of damaged roads in Dresden was also undertaken within the MEDIS project. The telephone surveys of affected households and companies following the 2002 flood were undertaken within the German Research Network Natural Disasters (DFNK), they were funded by Deutsche Rückversicherung AG and the BMBF (No. 01SFR9969/5). The telephone survey of affected households in the city of Dresden was undertaken within the MULTISURE project, funded by the BMBF (No. 0330755). The provision of data by the Saxon Dam Authority and the support of Jens Seifert (City of Dresden) and Steve Kobsch are gratefully acknowledged.

Edited by: M. Disse

Reviewed by: two anonymous referee

\section{References}

Apel, H., Aronica, G. T., Kreibich, H., and Thieken, A. H.: Flood risk analyses - how detailed do we need to be?, Nat. Hazards, 49(1), 79-98, doi:10.1007/s11069-008-9277-8, 2009.

Aronica, G. and Lanza, L.: Drainage efficiency in urban environment, Hydrol. Process., 19(5), 1105-1119, 2005.

Aronica, G., Nasello, C., and Tucciarelli, T.: 2D multilevel model for flood wave propagation in floodaffected areas, J. Water Res. Pl.-ASCE, 124(4), 210-217, 1998.

Bates, P. D. and De Roo, A. P. J.: A simple raster-based model for flood inundation simulation, J Hydrol (Amst), 236(1-2), 54-77, 2000.

Black, R. D.: Floodproofing Rural Residences, Report to the US Dept. of Commerce, Economic Development Administration, Washington DC, 1975.

BWG (Swiss Federal Office for Water and Geology (Publ.)): Hochwasserschutz an Fliessgewässern, Bern, 73 pp., 2001.

Claußen, L. and Clark, P. B.: The development of criteria for predicting dambreak flood damages using modelling historical dam failures, John Wiley Sons Ltd., Wallingford, 1990.

EDAC: Damage and loss prediction model based on engineering evaluation of the vulnerability of buildings subjected to natural hazard, http://www.edac.biz/index.php?id=46\\&L=1, 2008.

Engel, H.: The flood event 2002 in the River Elber basin causes of the flood, its course, statistical assessment and flood damages, Houille Blanche, 33-36, 2004.

Ganoulis, J.: Risk-based floodplain management: A case study from Greece, International Journal of River Basin Management, 1(1), 41-47, 2003.

Green, C.: Handbook of Water Economics: Principles and Practice, John Wiley and Sons, Chichester, 2003.

Grünthal, G. (Ed.), Musson, R., Schwarz, J., and Stucchi, M.: European Macroseismic Scale, Cahiers de Centre Européen de Géodynamique et de Seismologie, Luxembourg, Volume 15, 1998.

Harrison, S.: A complete history of the great flood at Sheffield, http://www2.shu.ac.uk/sfca/extra/A\%20Complete\%20History\% 20of\%20the\%20Great\%20Flood\%20at\%20Sheffield.pdf, 11 and 12 March 1864.
Hooijer, A., Klijn, F., Pedroli, G. B. M., and van Os, A. G.: Towards sustainable flood risk management in the Rhine and Meuse river basins: Synopsis of the findings of IRMA-SPONGE, River Res Applic, 20, 343-357, 2004.

ICPR (International Commission for the Protection of the Rhine): Non Structural Flood Plain Management - Measures and their Effectiveness, ICPR, Koblenz, 2002.

Kelman, I. and Spence, R.: A flood failure flowchart for buildings, Proceedings of the Institution of Civil Engineers - Municipal Engineer, 156, 207-214, 2003.

Kelman, I. and Spence, R.: An overview of flood actions on buildings, Eng. Geol., 73, 297-309, 2004

Kobsch, S.: Untersuchungen zur Ermittlung des Hochwasserschadens-Potentials in Siedlungs-, Industrieund Gewerbegebieten, Diploma thesis, Hochschule für Technik und Wirtschaft Dresden (FH), 86 pp., 2005.

Kreibich, H. and Thieken, A. H.: Assessment of damage caused by high groundwater inundation, Water Resour. Res., 44, W09409, doi:10.1029/2007WR006621, 2008.

Kreibich, H., Petrow, T., Thieken, A. H., Müller, M., and Merz, B.: Consequences of the extreme flood event of August 2002 in the city of Dresden, Germany, in: Sustainable Water Management Solutions for Large Cities, edited by: Savic, D. A., Marino, M. A., Savenije, H. H. G., and Bertoni, J. C., IAHS red book publ. 293, 164-173, 2005a.

Kreibich, H., Thieken, A. H., Petrow, Th., Müller, M., and Merz, B.: Flood loss reduction of private households due to building precautionary measures - lessons learned from the Elbe flood in August 2002, Nat. Hazards Earth Syst. Sci., 5, 117-126, 2005b, http://www.nat-hazards-earth-syst-sci.net/5/117/2005/.

Kreibich, H., Müller, M., Thieken, A. H., Petrow, T., and Merz, B.: Flood precaution of companies and their ability to cope with the flood in August 2002 in Saxony, Germany, Water Resour. Res., 43, W03408, doi:10.1029/2005WR004691, 2007.

Kreibich, H., Thieken, A. H., Grunenberg, H., Ullrich, K., and Sommer, T.: Extent, perception and mitigation of damage due to high groundwater levels in the city of Dresden, Germany, Nat. Hazards Earth Syst. Sci., 9, 1247-1258, 2009,

http://www.nat-hazards-earth-syst-sci.net/9/1247/2009/.

Maiwald, H.: Ingenieurmäßige Ermittlung von Hochwasserschadenspotentialen im mikroskaligen Maßstab, Dissertation, Department of Civil Engineering, Bauhaus-Universität Weimar, 2007.

McBean, E. A., Gorrie, J., Fortin, M., Ding, J., and Moulton, R.: Adjustment Factors for flood damage curves, J. Water Res. Pl.ASCE, 114(6), 635-646, 1988.

Merz, B. and Thieken, A. H.: Flood risk analysis: Concepts and challenges, Österreichische Wasser- und Abfallwirtschaft, 56(34), 27-34, 2004.

Mileti, D. S.: Disasters by design. A reassessment of natural hazards in the United States, Joseph Henry Press, Washington DC, 1999.

Penning-Rowsell, E. C. and Chatterton, J. B.: The benefits of flood alleviation: A manual of assessment techniques, Gower Technical Press, Aldershot, 1977.

Penning-Rowsell, E. C. and Green, C.: New Insights into the appraisal of flood-alleviation benefits: (1) Flood damage and flood loss information, J. Chart. Inst. Water. E., 14, 347-353, 2000. 
Penning-Rowsell, E. C., Johnson, C., Tunstall, S., Tapsell, S., Morris, J., Chatterton, J., and Green, C.: The benefits of Flood and Coastal Risk management, A Manual of Assessment Techniques, Middlesex University Press, 2006.

Petrow, T., Thieken, A. H., Kreibich, H., Bahlburg, C. H., and Merz, B:: Improvements on Flood Alleviation in Germany: Lessons Learned from the Elbe Flood in August 2002, Environ. Manage, 38, 717-732, 2006.

Rose, A., Porter, K., Dash, N., et al.: Benefit-Cost Analysis of FEMA Hazard Mitigation Grants, Natural Hazards Review, 8(4), 97-111, November, 2007.

Sayers, P., Hall, J., Dawson, R., Rosu, C., Chatterton, J., and Deakin, R.: Risk Assessment of Flood and coastal Defences for strategic Planning (RASP) - A high Level Methodology, DEFRA Conference of Coastal and River Engineers, Keele University, HR Wallingford, 2002.

Schwarz, J., Maiwald, H., and Gerstberger, A.: Quantifizierung der Schäden infolge Hochwassereinwirkung: Fallstudie Eilenburg, Bautechnik, 82(12), 845-856, 2005.

Schwarz, J. and Maiwald, H.: Prognose der Bauwerksschädigung unter Hochwassereinwirkung, Bautechnik, 84(7), 450-464, 2007.

Schwarz, J. and Maiwald, H.: Damage and loss prediction model based on the vulnerability of building types, 4th International Symposium on Flood Defence, Toronto, Canada, 6-8 May 2008.

SFOWG, SFOSD, SAEFL (Swiss Federal Office for Water and Geology, Swiss Federal Office for Spatial Development, Swiss Agency for the Environment, Forests and Landscape): Empfehlungen zur Berücksichtigung der Hochwassergefahren bei raumwirksamen Tätigkeiten, Bern, 1997.

SMI (Saxon Ministry of the Interior): Verwaltungsvorschrift des Sächsischen Staatsministeriums des Innern zur Behebung von Hochwasserschäden an Wohngebäuden (Administrative Regulation on the Compensation of flood damages of residential buildings), 8 pp., 2002 (in German).

Smith, D. I.: Actual and potential flood damage: a case study for urban Lismore, NSW, Australia, Appl. Geogr., 1, 31-39, 1981.
Smith, D. I.: Extreme floods and dam failure inundation implications for loss assessment, Proceedings of a Seminar "Natural and Technological Hazards: Implications for the Insurance Industry", 149-165, 1991.

Smith, D. I.: Flood damage estimation - A review of urban stagedamage curves and loss functions, Water SA, 20(3), 231-238, 1994.

SMUL (Saxon Ministry of Environment and Agriculture): Erstellung von flussgebietsbezogenen Hochwasserschutzkonzepten (HWSK), 28 pp., 2003 in German.

Soetanto, R. and Proverbs, D. G.: Impact of flood characteristics on damage caused to UK domestic properties: the perceptions of building surveyors, Structural Survey, 22(2), 95-104, 2004.

Stata Corp.: Stata 10 Base Reference Manual Set, StataCorp LP, College Station, Texas, 2007.

Thieken, A. H., Müller, M., Kreibich, H., and Merz, B.: Flood damage and influencing factors: New insights from the August 2002 flood in Germany, Water Resour. Res., 41, W12430, doi:101029/2005WR004177, 2005.

Thieken, A. H., Kreibich, H., Müller, M., and Merz, B.: Coping with floods: A survey among private households affected by the August 2002 flood in Germany, Hydrolog. Sci. J., 52(5), 10161037, 2007.

Thieken, A. H., Ackermann, V., Elmer, F., Kreibich, H., Kuhlmann, B., Kunert, U., Maiwald, H., Merz, B., Müller, M., Piroth, K., Schwarz, J., Schwarze, R., Seifert, I., and Seifert, J.: Methods for the evaluation of direct and indirect flood losses, in: Proceedings of the 4th International Symposium on Flood Defence, Toronto, Canada, CD-ROM, Paper 98, 1-10, 6-8 May 2008.

USACE (US Army Corps of Engineers): Risk-based analysis for flood damage reduction studies, Engineering Manual, 1110-21619, Washington DC, 1996.

Van der Veen, A. and Logtmeijer, C.: Economic hotspots: Visualizing vulnerability to flooding, Nat. Hazards, 36(1-2), 65-80, 2005.

Wind, H. G., Nierop, T. M., de Blois, C. J., and de Kok, J. L.: Analysis of flood damages from the 1993 and 1995 Meuse floods, Water Resour. Res., 35(11), 3459-3465, 1999. 